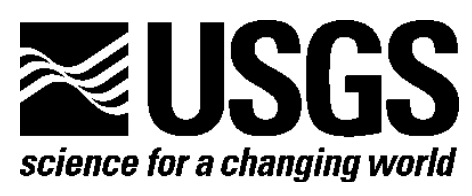

\title{
Regional Economic Impacts of Current and Proposed Management Alternatives for Don Edwards National Wildlife Refuge
}

By Leslie Richardson, Chris Huber, and Lynne Koontz

Open-File Report 2012-1094

U.S. Department of the Interior

U.S. Geological Survey 


\section{U.S. Department of the Interior \\ KEN SALAZAR, Secretary}

\section{U.S. Geological Survey \\ Marcia K. McNutt, Director}

U.S. Geological Survey, Reston, Virginia 2012

For more information on the USGS-the Federal source for science about the Earth, its natural and living resources, natural hazards, and the environment-visit http://www.usgs.gov or call 1-888-ASK-USGS

For an overview of USGS information products, including maps, imagery, and publications, visit $h t t p: / / w w w . u s g s . g o v / p u b p r o d$

To order this and other USGS information products, visit $h$ ttp://store.usgs.gov

Suggested citation:

Richardson, Leslie, Huber, Chris, and Koontz, Lynne, 2012, Regional economic impacts of current and proposed management alternatives for Don Edwards National Wildlife Refuge: U.S. Geological Survey, Open-File Report 2012-1094, 19 p.

Any use of trade, product, or firm names is for descriptive purposes only and does not imply endorsement by the U.S. Government.

Although this report is in the public domain, permission must be secured from the individual copyright owners to reproduce any copyrighted material contained within this report. 


\section{Contents}

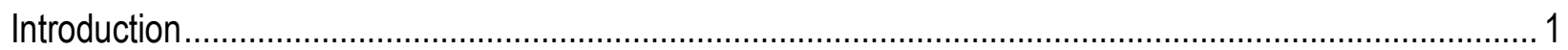

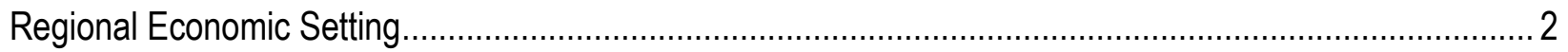

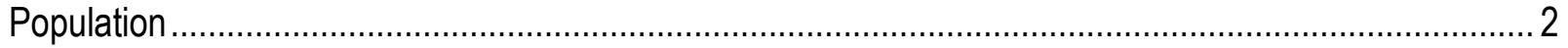

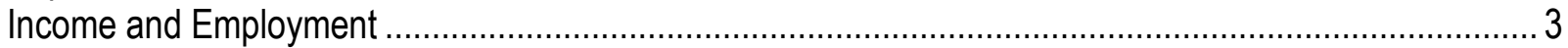

Silicon Valley, Education, and Industry .................................................................................. 4

Natural Resource-Based Industries ………………………………………………….... 5

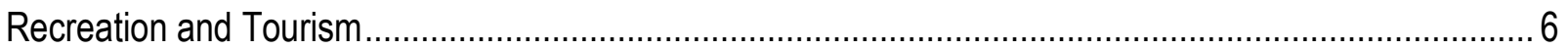

Economic Impacts of Current and Proposed Management Activities ..................................................... 7

Methods for a Regional Economic Impact Analysis …………......................................................

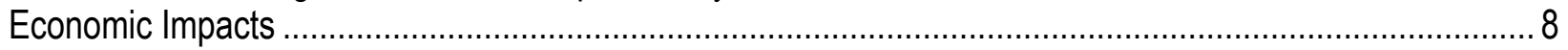

Impacts from Public Use and Access Management.................................................................... 8

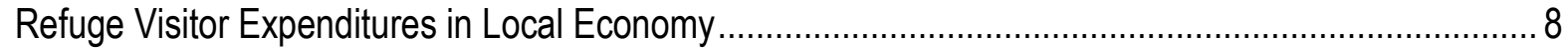

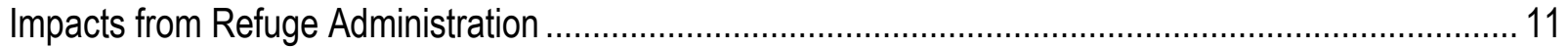

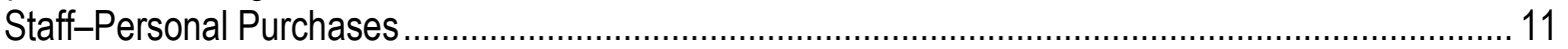

Work-Related Purchases............................................................................................................. 12

Summary of Economic Impacts for Alternative A (No Action Alternative) ............................................ 13

Summary of Economic Impacts for Alternative B ....................................................................... 13

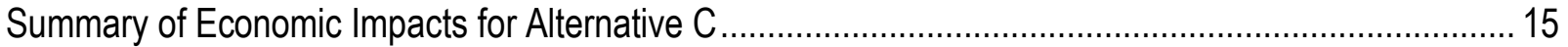

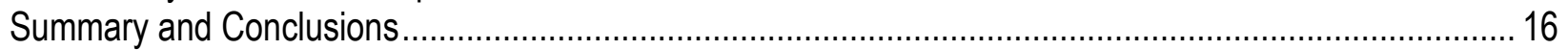

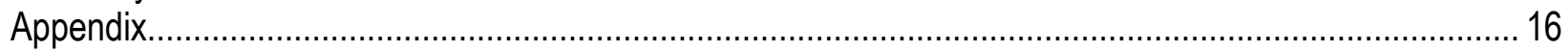

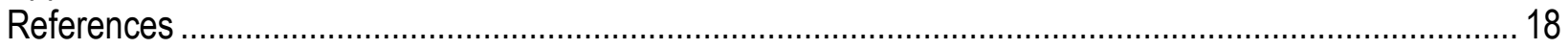

\section{Tables}

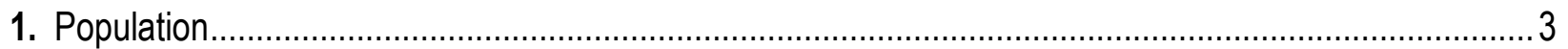

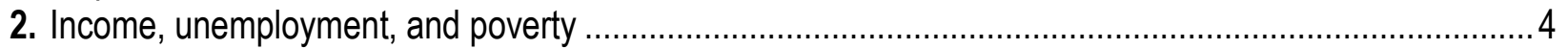

3. Percent of employment by sector ..........................................................................................

4. Estimated annual Don Edwards San Francisco Bay National Wildlife Refuge visitation by visitor

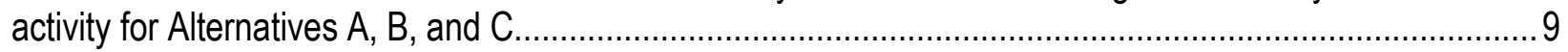

5. Annual impacts of non-local visitor spending for Alternatives $A, B$, and $C$......................................... 10

6. Current approved staff (Alternative $A$ ) and additional positions for Alternatives $B$ and $C$......................11

7. Annual local impacts of salary spending by Don Edwards San Francisco Bay National Wildlife

Refuge personnel for Alternatives A, B, and C ......................................................................... 12

8. Local economic impacts of Don Edwards San Francisco Bay National Wildlife Refuge related

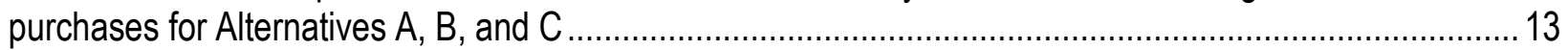

9. Economic impacts of Don Edwards San Francisco Bay National Wildlife Refuge management activities for Alternative A

10. Economic impacts of Don Edwards San Francisco Bay National Wildlife Refuge management activities for Alternative $B$ 14

11. Change in economic impacts under Alternative $B$ compared to Alternative $A$ 15 
12. Economic impacts of Don Edwards San Francisco Bay National Wildlife Refuge management activities for Alternative $\mathrm{C}$.

\section{Appendix Tables}

1-1. Estimated annual Don Edwards San Francisco Bay National Wildlife Refuge local and non-local visitation by visitor activity for Alternative $\mathrm{A}$

1-2. Total annual impacts of local and non-local visitor spending for Alternative A....................................17 


\title{
Regional Economic Impacts of Current and Proposed Management Alternatives for Don Edwards National Wildlife Refuge
}

\author{
By Leslie Richardson, Chris Huber, and Lynne Koontz
}

\section{Introduction}

The National Wildlife Refuge System Improvement Act of 1997 requires all units of the National Wildlife Refuge System to be managed under a Comprehensive Conservation Plan (CCP). The CCP must describe the desired future conditions of a Refuge and provide long-range guidance and management direction to achieve refuge purposes. The Don Edwards San Francisco Bay National Wildlife Refuge (NWR) is in the process of developing a range of management goals, objectives, and strategies for its CCP. The CCP must contain an analysis of expected effects associated with current and proposed Refuge management strategies.

For Refuge CCP planning, a regional economic analysis provides a means of estimating how current management (No Action Alternative) and proposed management activities (alternatives) would affect the local economy. This type of analysis provides two critical pieces of information: (1) it illustrates the Don Edwards San Francisco Bay NWR's contribution to the local community, and (2) it can help in determining whether economic effects are or are not a real concern in choosing among management alternatives.

For the purposes of an economic impact analysis, a region (and its economy) is typically defined as all counties within a 30-60 mile (mi) radius of the impact area. Only spending that takes place within this regional area is included as stimulating changes in economic activity. The size of the region influences both the amount of spending captured and the multiplier effects. The Don Edwards San Francisco Bay NWR is located at the south end of California's San Francisco Bay and is one of seven refuges in the San Francisco Bay NWR Complex. Most of the visitor spending associated with the Refuge is located within the three-county area of Alameda, San Mateo, and Santa Clara; therefore, these counties comprise the local economic region for this analysis.

It is important to note that the economic value of the Refuge encompasses more than just the impacts on the regional economy. The Refuge also provides substantial nonmarket values (values for items not exchanged in established markets) such as maintaining endangered species, preserving wetlands, educating future generations, and adding stability to the ecosystem (Carver and Caudill, 2007). However, quantifying these types of nonmarket values is beyond the scope of this study.

This report first presents a description of the local community and economy near the Don Edwards San Francisco Bay NWR. Next, the report describes methods used to conduct a regional economic impact analysis. An analysis of the final CCP management strategies that could affect stakeholders, residents, and the local economy is then presented. The management activities of economic concern in this analysis are:

- spending in the local community by refuge visitors; 
- refuge personnel salary spending; and

- refuge purchases of goods and services within the local community.

\section{Regional Economic Setting}

Alameda, San Mateo, and Santa Clara Counties compose the local economic region for the Don Edwards San Francisco Bay NWR. Collectively, these three counties have a population of 3,995,113 people and total area of approximately 2,478 square miles $\left(\mathrm{mi}^{2}\right)$ (U.S. Census Bureau, 2010). The Refuge is unique in that it was the first in the United States to be located in an urban setting when it opened in 1974, and due to its proximity to Silicon Valley (U.S. Fish and Wildlife Service, 2003).

\section{Population}

Table 1 shows the population estimates and trends for the regional areas and communities near the Refuge. In 2010, Alameda County accounted for approximately 4 percent of California's population, while San Mateo and Santa Clara Counties accounted for approximately 2 percent and 5 percent, respectively (U.S. Census Bureau, 2010). While California's population grew 9.1 percent from 2000 to 2009, Alameda, San Mateo, and Santa Clara Counties experienced relatively less growth at 3.3 percent, 1.7 percent, and 6.1 percent, respectively. The city of San Jose increased in population by 3.9 percent from 2000 to 2009, while the cities of Fremont and Newark declined in population by -0.80 percent and -1.4 percent during the same time period (U.S. Census Bureau, 2010).

Compared to the United States average, California has a higher percentage of the population under the age of 18. In 2009, California had a smaller percentage of the population in the 18-years-andover age demographic and the 65 years and over age demographic relative to the United States average (U.S. Census Bureau, 2011). However, California and the regional areas near the Refuge have shown signs of aging since 2000. The percentage of the California population aged 18-years-and-over has increased by 1.4 percent, while individuals 65 years and older have increased by 0.3 percent (U.S. Census Bureau, 2011). Alameda, San Mateo, and Santa Clara Counties have experienced similar patterns of aging. The percentage of the population in the 18 years and older age demographic for Alameda, San Mateo, and Santa Clara Counties has increased by 1.2 percent, 0.4 percent, and 0.1 percent, respectively, while the percentage of the population in the 65 years and over age demographic has increased by 0.5 percent, 1.1 percent, and 1.1 percent, respectively between 2000 and 2009 (U.S. Census Bureau, 2011).

The cities of Fremont and Newark are the primary communities near the Refuge in the East Bay region in Alameda County, Calif. The City of Fremont, home to the Refuge Visitor Center, has a population of 214,089, while its neighbor, Newark, has a population of 42,573 as of 2010 (U.S. Census Bureau, 2010). The residential community of Alviso, home to the Refuge's Environmental Education Center, and the city of San Jose are the primary communities near the Refuge at the south end of the San Francisco Bay, and are located in Santa Clara County, Calif. Although technically incorporated into the City of San Jose, the residential community of Alviso had a population of 2,128 in 2000, while San Jose has a population of 945,942, as of 2010 (U.S. Census Bureau, 2010).

Ethnically, each of the three counties near the Refuge had relatively fewer people identifying themselves as Hispanic or Latino than California's average in 2010 (U.S. Census Bureau, 2011). As a percentage of the population within each county, 23 percent in Alameda County, 25 percent in San Mateo County, and 26 percent in Santa Clara County, identified themselves as Hispanic or Latino. Comparatively, 38 percent of California's population identified himself or herself as Hispanic or Latino (U.S. Census Bureau, 2011). 
Table 1. Population

\begin{tabular}{|c|c|c|c|c|c|}
\hline & \multicolumn{4}{|c|}{ Population in 2010} & \multirow{2}{*}{$\begin{array}{c}\begin{array}{c}\text { Percentage } \\
\text { population change }\end{array} \\
2000-2009\end{array}$} \\
\hline & Residents & $\begin{array}{l}\text { People per } \\
\text { square mile }\end{array}$ & $\begin{array}{l}\text { Median age, } \\
2010\end{array}$ & $\begin{array}{c}\text { Percentage, } \\
\text { Bachelor's } \\
\text { degree or } \\
\text { higher }\end{array}$ & \\
\hline California & $37,253,956$ & 239.1 & 35.2 & 29.7 & 9.1 \\
\hline Alameda County, Calif. & $1,510,271$ & $2,046.4$ & 36.6 & 39.9 & 3.3 \\
\hline San Mateo County, Calif. & 718,451 & $1,600.1$ & 39.3 & 43.6 & 1.7 \\
\hline Santa Clara County, Calif. & $1,781,642$ & $1,382.4$ & 36.2 & 43.9 & 6.1 \\
\hline City of Fremont & 214,089 & $2,652.4$ & & 43.2 & -0.8 \\
\hline Newark & 42,573 & $3,040.2$ & & 24.2 & -1.4 \\
\hline City of San Jose & 945,942 & $5,118.1$ & & 31.6 & 3.9 \\
\hline Alviso $^{\mathrm{a}}$ & 2,128 & & & & \\
\hline
\end{tabular}

Source: U.S. Census Bureau, 2010; no updated median age for cities of Fremont, Newark, or San Jose;

${ }^{a}$ Alviso is an incorporated community of the city of San Jose, and does not have current population statistics other than Census data from the year 2000 (U.S. Census Bureau, 2010).

Racially, California has a higher percentage of the population identifying themselves as being of White ancestry compared to Alameda, San Mateo, and Santa Clara Counties. California's percentage of the population which identified as White was 58 percent, while Alameda, San Mateo, and Santa Clara Counties had 43 percent, 53 percent and 47 percent, respectively, in 2010 (U.S. Census Bureau, 2011). These three counties near the Refuge also have a higher percentage of the population that identified themselves as of Asian ancestry compared to California's population average. California's percentage of the population which identified as Asian was 13 percent, while Alameda, San Mateo, and Santa Clara Counties had 26 percent, 25 percent and 32 percent, respectively, in 2010 (U.S. Census Bureau, 2011).

The counties and communities near the Refuge have a higher level of educational attainment compared to California's population average. Table 1 shows how California, the nearby counties, and the communities near the Refuge differ in terms of percentage of the population with a Bachelor's degree or higher (U.S. Census Bureau, 2010). Except for Newark, Calif. (with 24.2 percent of the population), each county and primary city near the Refuge had a higher percentage of the population with a Bachelor's degree of higher than the California average at 29.7 percent. The highest was Santa Clara County, with 43.9 percent of the population with a Bachelor's degree or higher (U.S. Census Bureau, 2010).

\section{Income and Employment}

Median household income, unemployment rate, and the percentage of the population living below the Federal poverty line for each county and primary community near the Refuge are listed in table 2 . The regional counties and communities near the Refuge are relatively more affluent than the U.S. and California population averages. As of 2009 , each county and primary community near the Refuge had a higher median household income level than the U.S average $(\$ 50,221$ per year; U.S. Census Bureau, 2009b). Of the three counties near the Refuge, Santa Clara County had the highest level 
of median household income ( $\$ 84,990$ per year). The City of Fremont, Calif. had the highest level of median income of the primary communities near the Refuge $(\$ 88,645$ per year).

Table 2. Income, unemployment, and poverty

\begin{tabular}{|c|c|c|c|c|c|}
\hline & $\begin{array}{c}\text { Median } \\
\text { household }\end{array}$ & Unen & nt rate & $\begin{array}{c}\text { Percentage } \\
\text { unemployment }\end{array}$ & Percentage of \\
\hline & $\begin{array}{l}\text { income, } \\
2009\end{array}$ & 2008 & 2011 & $\begin{array}{c}\text { change, } \\
\text { 2008-2011 }\end{array}$ & poverty, 2009 \\
\hline United States & $\$ 50,221$ & 4.9 & 9.0 & 4.1 & 14.3 \\
\hline California & $\$ 58,925$ & 6.4 & 11.7 & 5.3 & 14.2 \\
\hline Alameda County & $\$ 68,258$ & 6.1 & 10.3 & 4.2 & 10.8 \\
\hline San Mateo County & $\$ 84,678$ & 4.8 & 8.2 & 3.4 & 7.6 \\
\hline Santa Clara County & $\$ 84,990$ & 6.0 & 9.9 & 3.9 & 9.1 \\
\hline City of Fremont & $\$ 88,645$ & 4.4 & 7.5 & 3.1 & \\
\hline Newark & $\$ 78,367$ & 5.7 & 9.6 & 3.9 & \\
\hline City of San Jose & $\$ 76,354$ & 6.6 & 11.0 & 4.4 & \\
\hline Alviso $^{\mathrm{a}}$ & & & & & \\
\hline
\end{tabular}

Sources: U.S. Census Bureau, 2009b (mean household income and percent of individuals below poverty in 2009)

Employment Development Department, 2011a (state and county unemployment in California)

Employment Development Department, 2011 b (labor force and unemployment rate for cities and census designated places)

Bureau of Labor Statistics-United States Department of Labor, 2011 (United States unemployment)

${ }^{a}$ Residential community of Alviso has no current data available

From 2008 to 2010 the unemployment rate steadily increased in each county and community near the Refuge, while 2011 saw a slight decrease in the level of unemployment from 2010 (U.S. Census Bureau, 2009b). With the U.S. unemployment rate in April, 2011 at 9.0 percent, the California unemployment rate has remained much higher at 11.7 percent (Bureau of Labor Statistics-U.S. Department of Labor, 2011; Employment Development Department, 2011a). Similarly, each county near the Refuge had unemployment levels higher than the national average in 2011, with the exception of San Mateo County. This trend has persisted since 2008 with Alameda and Santa Clara Counties having levels of unemployment higher than the national average, while San Mateo County's unemployment level has consistently been lower than the national average. The communities near the Refuge have experienced a similar pattern of increasingly high levels of unemployment since 2008 (Employment Development Department, 2011b). The city of San Jose (including incorporated residential community of Alviso, Calif.) has consistently had the highest level of unemployment of the cities near the Refuge, which peaked in 2010 at 12.4 percent (the same rate as the State of California at the time) (Employment Development Department, 2011b).

\section{Silicon Valley, Education, and Industry}

Regionally, the counties and communities near the Refuge have been popularized as "Silicon Valley," and historically high concentrations of technology based industries have been located in the area. While self-proclaimed as the "Capital of Silicon Valley," the city of San Jose, located in Santa 
Clara County, is considered the center of this technological industrial complex, but the remaining regional communities and counties follow a similar pattern of development.

Table 3 provides a weighted average of Alameda, San Mateo, and Santa Clara Counties, into what is labeled as "Region near refuge" (U.S. Census Bureau, 2009a). As a region, manufacturing, professional services, educational services, health care, and social assistance are significant economic drivers with a combined estimate of 50.7 percent of all employment in these sectors. Top-ten major high-tech employers in the city of San Jose (each with at least 1,100 employees) include Cisco Systems, IBM, eBay, Hitachi, and Adobe Systems (Department of Planning, Building, and Code Enforcement, 2011; Office of Economic Development, 2010). Other notable technology employers located in Alameda, San Mateo, Santa Clara Counties include Google, Hewlett-Packard, Intel, Yahoo!, Facebook, and Apple.

Table 3. Percent of employment by sector.

\begin{tabular}{lc}
\hline \multicolumn{1}{c}{ Employment sector } & Region near refuge \\
\hline Total non-farm employment & $1,941,345$ \\
Agriculture, forestry, fishing, hunting, and mining & $0.4 \%$ \\
Construction & $6.3 \%$ \\
Manufacturing & $14.4 \%$ \\
Wholesale trade & $2.9 \%$ \\
Retail trade & $9.8 \%$ \\
Transportation, warehousing, and utilities, & $4.4 \%$ \\
Information & $3.7 \%$ \\
Finance, insurance, real estate & $6.3 \%$ \\
Professional, scientific, administrative, and waste & $16.8 \%$ \\
Educational services, health care, and social assistance & $19.5 \%$ \\
Arts, entertainment, recreation, accommodation, and food services & $7.6 \%$ \\
Other services & $4.7 \%$ \\
Public administration & $3.2 \%$ \\
\hline
\end{tabular}

Source: U.S. Census Bureau, 2009a

The development of Silicon Valley as a technological center has been greatly influenced by experimentation and innovation from Stanford University (Markoff, 2009). Since the 1940s and 1950s, Stanford University (located in Santa Clara County and approximately 20 mi northwest of San Jose) has encouraged students to develop businesses near campus to encourage regional economic development. Also in Santa Clara County is San Jose State University; it is located in downtown San Jose, Calif. To the north of the city of San Jose in the East Bay region is the University of California, Berkeley, which is located in Alameda County, Calif.

\section{Natural Resource-Based Industries}

The San Francisco Bay area was once the center of commercial fishing on the West Coast, but was heavily exploited to the point where the bay experienced a decline in fishery products as early as 1900 (Smith and Kato, 1979). Regulation has since slowed commercial fishing in the San Francisco Bay, although commercial fishing still exists and is managed by the California Department of Fish and Game. As of 2011, commercial fishing is allowed near the Refuge in Alameda and San Mateo Counties 
for kelp, finfish, pelagic finfish, Dungeness crab, squid, and giant kelp (California Department of Fish and Game, 2011). In 2009, the San Francisco Bay area produced a total of approximately $\$ 9.2$ million from commercial fishing (California Department of Fish and Game, 2010).

Cargill, Incorporated has historically been the primary contributor of land for the Refuge through the selling and donating of land previously used as evaporative ponds for commercial salt production (Cargill, Inc., 2005). The first transfer was in 1979 and created the Don Edwards San Francisco Bay National Wildlife Refuge. The largest transfer was in 2003 when Cargill donated and sold 16,500 acres of land to Federal and State agencies. Since 1979, Cargill has donated and sold more than $65 \mathrm{mi}^{2}$ of land for the Refuge (Cargill, Inc., 2005). Through a collaborative effort, Cargill and wildlife agencies have frequently worked together to reduce the salinity of the salt ponds and restore them for wildlife habitat.

In addition to the efforts of Cargill and wildlife agencies, the San Francisco Bay Wildlife Society has been a significant contributor to the efforts of managing and expanding the Don Edwards San Francisco National Wildlife Refuge to what it is today. Since 1987, when incorporated as a non-profit, the San Francisco Bay Wildlife Society has coordinated with the U.S. Fish and Wildlife Service in supporting education, interpretation, and research at the Refuge (San Francisco Bay Wildlife Society, 2010). It also promotes summer camps in Fremont, Alviso, and East Palo Alto (found in Santa Clara County, Calif.), and provides funding for environmental education at the Environmental Education Center in Alviso, Calif.

\section{Recreation and Tourism}

According to the 2006 National Survey of Fishing, Hunting, and Wildlife-Associated Recreation, approximately 7.4 million residents participated in wildlife-associated recreation activities in California in 2006 (U.S. Fish and Wildlife Service and U.S. Census Bureau, 2008). Of the total number of participants, 23 percent fished, 4 percent hunted, and 85 percent engaged in wildlifewatching activities. It was estimated that California residents and visitors combined spent $\$ 8$ billion on these wildlife-associated recreation activities in 2006. From 1996 to 2006, it was found that the number of California residents who went fishing declined by 38 percent, hunting declined by 45 percent, and wildlife viewing numbers remained relatively constant.

The Public Opinions and Attitudes Survey 2007 found that in general, Californians tended to participate in more affordable and less technical outdoor recreational activities such as walking for fitness/pleasure, driving for pleasure/sightseeing, beach activities, swimming in a pool, and day hiking on trails (California State Parks, 2009). The Santa Clara County Park system currently has 45,000 acres of open space for activities such as golfing, archery, wildlife observation, hiking, and so forth (Department of Parks and Recreation, 2011). At the south end of the San Francisco Peninsula in San Mateo County, the Parks Department manages designated areas and programs for camping, hiking, picnics, bicycling, equestrian, and youth camps (Department of Parks, 2011). In Alameda County, The City of Fremont offers recreation opportunities at 52 parks, the community gymnasium, waterpark, tennis courts, and five community centers (Recreation Services, 2011). East Bay neighbor, Newark, has approximately 153 acres of open space across 15 parks and sports facilities (Recreation and Community Service, 2011).

According to the 2009 Annual Report on residential recreation and use of parks, the City of San Jose had $53 \mathrm{mi}$ of trails, 55 community centers, 15 golf courses, 250 playgrounds, and 179 neighborhood parks (Parks, Recreation and Neighborhood Services, 2009). According to the report, 85 percent of San Jose households visited a San Jose park or outdoor recreation facility, while 35 percent of households are "frequent users" of these sites. Further, the report found that 70 percent of residents used a San Jose trail or walkway in 2009. 


\section{Economic Impacts of Current and Proposed Management Activities}

\section{Methods for a Regional Economic Impact Analysis}

Economic input-output models are commonly used to determine how economic sectors will and will not be affected by demographic, economic, and policy changes. The economic impacts of the management alternatives for the Don Edwards San Francisco Bay NWR were estimated using Impact Analysis for Planning (IMPLAN), a regional input-output modeling system developed by the USDA Forest Service. The IMPLAN program is a computerized database and modeling system that provides a regional input-output analysis of economic activity in terms of 10 industrial groups involving more than four hundred economic sectors (Olson and Lindall, 1999). The IMPLAN model draws upon data collected by the Minnesota IMPLAN Group from multiple Federal and State sources including the Bureau of Economic Analysis, Bureau of Labor Statistics, and the U.S. Census Bureau (Olson and Lindall, 1999). The year 2009 IMPLAN data profiles for Alameda, San Mateo, and Santa Clara Counties were used in this study. The IMPLAN county-level employment data estimates were found to be comparable to the U.S. Department of Commerce, Bureau of Economic Analysis, Regional Economic Information System data for the year 2009.

Because of the way industries interact in an economy, activity in one industry affects activity levels in several other industries. For example, if more visitors come to an area, local businesses will purchase extra labor and supplies to meet the increase in demand for additional services. The income and employment resulting from visitor purchases from local businesses represent the direct effects of visitor spending within the economy. Direct effects measure the net amount of spending that stays in the local economy after the first round of spending; the amount that doesn't stay in the local economy is termed a leakage (Carver and Caudill, 2007). In order to increase supplies to local businesses to meet increased demand, input suppliers must also increase their purchases of inputs from other industries. The income and employment resulting from these secondary purchases by input suppliers are the indirect effects of visitor spending within the economy. Employees of the directly affected businesses and input suppliers use their incomes to purchase goods and services. The resulting increased economic activity from new employee income is the induced effect of visitor spending. The indirect and induced effects are known as the secondary effects of visitor spending. "Multipliers" (or "response coefficients") capture the size of the secondary effects, usually as a ratio of total effects to direct effects (Stynes, 1998). The sums of the direct and secondary effects describe the total economic impact of visitor spending in the local economy.

There are three alternatives evaluated in the Don Edwards San Francisco Bay NWR CCP. For each alternative, regional economic effects from the IMPLAN model are reported for the following categories:

- Employment represents the change in the number of jobs generated in the region from a change in regional output. IMPLAN estimates for employment include both full-time and part-time workers; workers are measured in total jobs.

- Labor income includes employee wages and salaries, including income of sole proprietors and payroll benefits.

- Value added measures contribution to Gross Domestic Product. Value added is equal to the difference between the amount an industry sells a product for and the production cost of the product, and is thus net of intermediate sales.

The CCP provides long range guidance and management direction to achieve the Refuge purposes over a 15-year timeframe. The economic impacts reported in this report are on an annual basis in 2010 dollars. Large management changes often take several years to achieve. The estimates reported 
for Alternatives B and C represent the final economic effects after all changes in management have been implemented.

\section{Economic Impacts}

\section{Impacts from Public Use and Access Management}

\section{Refuge Visitor Expenditures in Local Economy}

Spending associated with recreational visits to National Wildlife Refuges generates significant economic activity. The FWS report "Banking on Nature: The Economic Benefits of National Wildlife Refuges Visitation to Local Communities" estimated the impact of National Wildlife Refuges on their local economies (Carver and Caudill, 2007). According to the report, more than 34.8 million visits were made to National Wildlife Refuges in FY 2006; this generated \$1.7 billion of sales in regional economies. Accounting for both the direct and secondary effects, spending by National Wildlife Refuge visitors generated nearly 27,000 jobs, and more than \$542.8 million in employment income (Carver and Caudill, 2007). Approximately eighty-two percent of total expenditures were from non-consumptive activities, twelve percent from fishing, and six percent from hunting (Carver and Caudill, 2007).

The Don Edwards San Francisco Bay NWR offers a wide variety of year round accessible recreational opportunities associated with the "big-six" wildlife-dependent uses: wildlife observation and photography, interpretation, environmental education, hunting, and fishing. While waterfowl hunting and fishing by boat is allowed in certain areas of the Refuge, wildlife observation is the primary visitor activity that occurs on the Don Edwards San Francisco Bay NWR. The Refuge contains hundreds of animal species and is designed to provide a diversity of wildlife viewing opportunities in a manner that minimizes disturbance to wildlife. Free weekend programs are offered, along with a wide range of environmental education programs.

This section focuses on the local economic impacts associated with Don Edwards San Francisco Bay NWR visitation. Annual visitation estimates for the Refuge are based on several Refuge statistic sources including: visitors entering the Visitor Center/Office, hunting permits, and general observation by Refuge personnel. Annual visitation estimates are on a per-visit basis. Table 4 summarizes estimated visitation by type of visitor activity for Alternatives A, B, and C. All of the "big six" uses would be provided to some degree on the Don Edwards San Francisco Bay NWR across all three alternatives. A primary emphasis for the Refuge's public-use program would continue to be on providing high quality wildlife observation and interpretation opportunities, resulting in substantial increases in wildlife observation visits under Alternatives B and C. Proposed updates to a fishing pier and installation of an additional fishing platform would result in increased fishing visits under Alternatives B and C. Construction of an additional hunting blind and hunting-education classes would result in increased hunting visits under Alternative $\mathrm{C}$.

To determine the local economic impacts of visitor spending, only data for spending by persons living outside of the local three-county area are included in the analysis. ${ }^{1}$ The rationale for excluding local-visitor spending is twofold. First, money flowing into the local three-county area from visitors living outside the local area (hereafter referred to as non-local visitors) is considered new money injected into the local economy. Second, if residents of the local three-county area visit the Refuge more or less due to the management changes, they will correspondingly change the spending of their money

\footnotetext{
${ }^{1}$ An analysis of the local economic significance of visitor spending by persons living both inside and outside of the local three-county area for the current Alternative A can be found in the Appendix.
} 
elsewhere in that local area, resulting in no net change to the local economy. These are standard assumptions made in most regional economic analyses at the local level. Refuge personnel determined the percentage of non-local Refuge visitors. Table 4 shows the estimated percent of non-local Refuge visits and visitor days under each alternative.

A visitor usually buys a wide range of goods and services while visiting an area. Major expenditure categories include lodging, restaurants, supplies, groceries, and recreational equipment rental. In this analysis we use average daily visitor spending profiles from the Banking on Nature report (Carver and Caudill, 2007) that were derived from the 2006 National Survey of Fishing, Hunting, and Wildlife Associated Recreation (U.S. Fish and Wildlife Service and U.S. Census Bureau, 2008). The National Survey reports trip related spending of State residents and non-residents for several different wildlife-associated recreational activities. For each recreation activity, spending is reported in the categories of lodging, food and drink, transportation, and other expenses. Carver and Caudill (2007) calculated the average per-person per-day expenditures by recreation activity for each FWS region. We used the spending profiles for nonresidents for FWS Region 1 (for the purposes of the analysis in the Banking on Nature report, Region 1 includes California), and updated the 2006 spending profiles to 2010 dollars using the Consumer Price Index Inflation Calculator. Average daily spending profiles for nonresident visitors to Region 1 for fishing (\$63.96 per day) and waterfowl and other migratory bird hunting ( $\$ 186.83$ per day) were used to estimate non-local visitor spending for Refuge fishing and hunting related activities. The average daily nonresident spending profile for non-consumptive wildlife

Table 4. Estimated annual Don Edwards San Francisco Bay National Wildlife Refuge visitation by visitor activity for Alternatives A, B, and C.

\begin{tabular}{lccccc}
\hline \multicolumn{1}{c}{ Visitor activity } & $\begin{array}{c}\text { Total } \\
\text { number of } \\
\text { visits }\end{array}$ & $\begin{array}{c}\text { Percentage } \\
\text { of non-local } \\
\text { visits }\end{array}$ & $\begin{array}{c}\text { Total } \\
\text { number of } \\
\text { non-local } \\
\text { visits }\end{array}$ & $\begin{array}{c}\text { Number of } \\
\text { hours spent } \\
\text { at refuge }\end{array}$ & $\begin{array}{c}\text { Number of } \\
\text { non-local } \\
\text { visitor } \\
\text { days }\end{array}$ \\
\hline $\begin{array}{l}\text { Alternative A } \\
\quad \text { Fishing }\end{array}$ & 3,700 & 10 & 370 & 4 & 185 \\
$\quad \begin{array}{l}\text { Waterfowl hunting } \\
\text { Nature trails/other wildlife } \\
\text { observation }\end{array}$ & 3,900 & 10 & 390 & 6 & 293 \\
Total visitation & 746,341 & 10 & 74,634 & 2 & 18,659 \\
\hline $\begin{array}{l}\text { Alternative B } \\
\text { Fishing }\end{array}$ & 753,941 & & 75,394 & & 19,137 \\
$\quad \begin{array}{l}\text { Waterfowl hunting } \\
\text { Nature trails/other wildlife } \\
\text { observation }\end{array}$ & 4,070 & 10 & 407 & 4 & 204 \\
Total visitation & 3,900 & 10 & 390 & 6 & 293 \\
\hline Alternative C & 970,243 & 10 & 97,024 & 2 & 24,256 \\
$\quad \begin{array}{l}\text { Fishing } \\
\text { Waterfowl hunting }\end{array}$ & 978,213 & & 97,821 & & 24,753 \\
$\begin{array}{l}\text { Nature trails/other wildlife } \\
\text { observation }\end{array}$ & 4,070 & 10 & 407 & 4 & 204 \\
Total visitation & 4,095 & 10 & 410 & 6 & 307 \\
\hline
\end{tabular}

${ }^{\mathrm{a}}$ One visitor day $=8$ hours. 
recreation (observing, feeding, or photographing fish and wildlife) was used for non-consumptive wildlife-viewing activities (\$117.87 per day).

Visitor spending profiles are estimated on an average-per-day ( 8 hours) basis. Because some visitors only spend short amounts of time visiting a refuge, counting each refuge visit as a full visitor day would overestimate the economic impact of Don Edwards San Francisco Bay NWR visitation. In order to properly account for the amount of spending, the annual number of non-local refuge visits were converted to visitor days. Refuge personnel estimate that non-local anglers spend approximately 4 hours (half a visitor day) on the Refuge, while waterfowl hunters spend approximately 6 hours (3/4 a visitor day). Non-local visitors that view wildlife on nature trails or participate in other wildlife observation activities typically spend 2 hours (1/4 a visitor day). Table 4 shows the number of non-local visitor days by recreation activity for each alternative.

Total spending by non-local Refuge visitors was determined by multiplying the average nonlocal visitor daily spending by the number of non-local visitor days at the Refuge. Table 5 summarizes the total economic impacts associated with current non-local visitation by alternative. Under Alternative A, non-local Don Edwards San Francisco Bay NWR visitors would spend more than \$2.2 million in the local economy annually. This spending would directly account for 13 jobs, $\$ 615,500$ in labor income, and $\$ 1.03$ million in value added in the local economy. The secondary or multiplier effects would generate an additional 8 jobs, $\$ 406,600$ in labor income, and $\$ 702,000$ in value added. Accounting for both the direct and secondary effects, spending by non-local visitors for Alternative A would generate total economic impacts of 21 jobs, $\$ 1.02$ million in labor income, and $\$ 1.73$ million in value added.

Table 5. Annual impacts of non-local visitor spending for Alternatives A, B, and C.

\begin{tabular}{lccc}
\hline & $\begin{array}{c}\text { Employment } \\
\text { (number of full- and } \\
\text { part-time jobs) }\end{array}$ & $\begin{array}{c}\text { Labor income } \\
\text { (in thousands of dollars, } \\
\text { 2010) }\end{array}$ & $\begin{array}{c}\text { Value added } \\
\text { (in thousands of dollars, } \\
\text { 2010) }\end{array}$ \\
\hline Alternative A & 13.4 & $\$ 615.5$ & $\$ 1,027.7$ \\
$\quad$ Direct effects & 7.6 & $\$ 406.6$ & $\$ 702.0$ \\
$\quad$ Secondary effects & 21.0 & $\$ 1,022.1$ & $\$ 1,729.7$ \\
Total economic impact & & & \\
\hline Alternative B & 17.3 & $\$ 795.3$ & $\$ 1,328.0$ \\
$\quad$ Direct effects & 9.9 & $\$ 525.6$ & $\$ 907.4$ \\
Secondary effects & 27.2 & $\$ 1,320.9$ & $\$ 2,235.4$ \\
Total economic impact & & & $\$ 1,429.1$ \\
\hline Alternative C & 18.7 & $\$ 855.9$ & $\$ 976.5$ \\
Direct effects & 10.6 & $\$ 565.6$ & $\$ 2,405.6$ \\
$\quad$ Secondary effects & 29.3 & $\$ 1,421.5$ & \\
Total economic impact & &
\end{tabular}

As shown in Table 4, Don Edwards San Francisco Bay NWR non-local visitation for all activities is anticipated to increase by 5,616 visitor days under Alternative B as compared to Alternative A. Under Alternative B, non-local Don Edwards San Francisco Bay NWR visitors would spend more than $\$ 2.9$ million in the local area annually. Accounting for both the direct and secondary effects, spending by non-local visitors for Alternative B would generate total economic impacts of 27 jobs, $\$ 1.32$ million in labor income, and \$2.24 million in value added. 
Don Edwards San Francisco Bay NWR non-local visitation across all activities is anticipated to increase by 7,496 visitor days under Alternative $\mathrm{C}$ as compared to Alternative A (Table 4). Under Alternative C, non-local Don Edwards San Francisco Bay NWR visitors would spend more than \$3.1 million in the local area annually. Accounting for both the direct and secondary effects, spending by non-local visitors for Alternative $\mathrm{C}$ would generate total economic impacts of 29 jobs, \$1.42 million in labor income, and \$2.41 million in value added.

\section{Impacts from Refuge Administration}

\section{Staff-Personal Purchases}

Employees of the Don Edwards San Francisco Bay NWR reside and spend their salaries on daily living expenses in the local area, thereby generating impacts within the local economy. Householdconsumption expenditures consist of payments by individuals/households to industries for goods and services used for personal consumption. The IMPLAN modeling system contains household consumption spending profiles that account for average household spending patterns by income level. These profiles allow for leakage of household spending to outside the region. The current approved Refuge staff consists of 10 employees for Alternative A and is anticipated to increase to 27.5 employees under Alternative B and 31.5 employees under Alternative C, as shown in Table 6.

Table 6. Current approved staff (Alternative A) and additional positions for Alternatives B and C.

\begin{tabular}{lll}
\multicolumn{1}{c}{ Alternative A } & \multicolumn{1}{c}{$\begin{array}{c}\text { Additional positions for } \\
\text { Alternative B }\end{array}$} & \multicolumn{1}{c}{$\begin{array}{c}\text { Additional positions for } \\
\text { Alternative C }\end{array}$} \\
\hline Refuge Manager & Botanist & Botanist \\
Wildlife Refuge Specialist (1.5) & Wildlife Biologist (2) & Wildlife Biologist (3) \\
Maintenance Worker (2) & Wildlife Refuge Specialist (2) & Wildlife Refuge Specialist (2) \\
Wildlife Biologist (2) & Biological Science Technician (4) & Biological Science Technician (4) \\
Environmental Education Specialist & Interpretive Park Ranger & Interpretive Park Ranger \\
$(1.5)$ & Environmental Education Specialist & Environmental Education Specialist (2) \\
Instructional Systems Specialist (0.5) & Environmental Education Specialist ${ }^{\mathrm{a}}$ & Environmental Education Specialsit \\
Interpretive Park Ranger & Visitor Services Information Assistant & Visitor Services Information Assistant \\
Outdoor Recreation Planner (0.5) & $(2)$ & $(2)$ \\
& Law Enforcement Officer & Law Enforcement Officer \\
& Information Technology Specialist & Information Technology Specialist \\
& $(0.5)$ & (1.5) \\
& Maintenance Worker & Maintenance Worker (2) \\
& Administrative Support Assistant & Administrative Support Assistant \\
\hline Total positions $=10$ & Total positions $=27.5$ & Total positions $=31.5$ \\
\hline
\end{tabular}

${ }^{\mathrm{a} C o n t i n g e n c y ~ p o s i t i o n ~ b a s e d ~ o n ~ g r a n t ~ f u n d i n g . ~}$

Refuge personnel estimate that current annual salaries total around $\$ 843,600$ under Alternative A and would increase to $\$ 1.78$ million and $\$ 2.04$ million under Alternatives B and C, respectively. Table 7 shows the economic impacts associated with spending salaries in the local three-county area by Don Edwards San Francisco Bay NWR employees under Alternatives A, B, and C. For Alternative A, salary spending by Don Edwards San Francisco Bay NWR personnel would generate additional secondary effects of 4 jobs, $\$ 231,300$ in labor income, and $\$ 417,700$ in value added in the local economy. For Alternative B, salary spending by Don Edwards San Francisco Bay NWR personnel 
would generate additional secondary effects of 9 jobs, $\$ 487,500$ in labor income, and \$880,200 in value added in the local economy. For Alternative C, salary spending would generate additional secondary effects of 10 jobs, $\$ 558,900$ in labor income, and more than $\$ 1$ million in value added.

Table 7. Annual local impacts of salary spending by Don Edwards San Francisco Bay National Wildlife Refuge personnel for Alternatives $A, B$, and C.

\begin{tabular}{|c|c|c|c|}
\hline & $\begin{array}{l}\text { Employment } \\
\text { (number of full- and } \\
\text { part-time jobs) }\end{array}$ & $\begin{array}{l}\text { Labor income } \\
\text { (in thousands of dollars, } \\
\text { 2010) }\end{array}$ & $\begin{array}{c}\text { Value added } \\
\text { (in thousands of dollars, } \\
\text { 2010) }\end{array}$ \\
\hline \multicolumn{4}{|l|}{ Alternative A } \\
\hline Direct effects & & $\$ 0.0$ & $\$ 0.0$ \\
\hline Secondary effects & 4.2 & $\$ 231.3$ & $\$ 417.7$ \\
\hline Total economic impact & 4.2 & $\$ 231.3$ & $\$ 417.7$ \\
\hline \multicolumn{4}{|l|}{ Alternative B } \\
\hline Direct effects & 0.0 & $\$ 0.0$ & $\$ 0.0$ \\
\hline Secondary effects & 8.9 & $\$ 487.5$ & $\$ 880.2$ \\
\hline Total economic impact & 8.9 & $\$ 487.5$ & $\$ 880.2$ \\
\hline \multicolumn{4}{|l|}{ Alternative $\mathbf{C}$} \\
\hline Direct effects & 0.0 & $\$ 0.0$ & $\$ 0.0$ \\
\hline Secondary effects & 10.2 & $\$ 558.9$ & $\$ 1,009.2$ \\
\hline Total economic impact & 10.2 & $\$ 558.9$ & $\$ 1,009.2$ \\
\hline
\end{tabular}

\section{Work-Related Purchases}

A wide variety of supplies and services are purchased for Refuge operations and maintenance activities. Refuge purchases made in the local three-county area contribute to the local economic impacts associated with the Don Edwards San Francisco Bay NWR. Major local expenditures include: supplies and services related to building maintenance and construction; auto repairs, parts, and fuel; and utilities. Average annual non-salary expenditures are anticipated to be $\$ 830,614$ for Alternative A, $\$ 1.22$ million for Alternative B, and \$1.18 million for Alternative C. According to Refuge records, approximately 75 percent of the annual non-salary budget expenditures are spent on goods and services purchased in the local three-county area. Table 8 shows the economic impacts associated with workrelated expenditures in local communities near the Don Edwards San Francisco Bay NWR. For Alternative A, work-related purchases would generate a total economic impact of 5 jobs, $\$ 363,400$ in labor income, and $\$ 617,700$ in value added. Work-related purchases under Alternative B would generate a total economic impact of 7 jobs, $\$ 533,000$ in labor income, and $\$ 905,900$ in value added. For Alternative $C$, work-related purchases would generate a total economic impact of 7 jobs, $\$ 516,600$ in labor income, and $\$ 878,100$ in value added. 
Table 8. Local economic impacts of Don Edwards San Francisco Bay National Wildlife Refuge related purchases for Alternatives $A, B$, and $C$.

\begin{tabular}{lccc}
\hline & $\begin{array}{c}\text { Employment } \\
\text { (number of full- and } \\
\text { part-time jobs) }\end{array}$ & $\begin{array}{c}\text { Labor income } \\
\text { (in thousands of dollars, } \\
\text { 2010) }\end{array}$ & $\begin{array}{c}\text { Value added } \\
\text { (in thousands of dollars, } \\
\text { 2010) }\end{array}$ \\
\hline Alternative A & 3.1 & $\$ 234.6$ & $\$ 395.4$ \\
Direct effects & 1.9 & $\$ 128.8$ & $\$ 222.3$ \\
Secondary effects & 5.0 & $\$ 363.4$ & $\$ 617.7$ \\
Total economic impact & & & \\
\hline Alternative B & 4.6 & $\$ 344.1$ & $\$ 579.9$ \\
Direct effects & 2.7 & $\$ 188.9$ & $\$ 326.0$ \\
Secondary effects & 7.3 & $\$ 533.0$ & $\$ 905.9$ \\
Total economic impact & & & \\
\hline Alternative C & 4.4 & $\$ 333.5$ & $\$ 562.1$ \\
Direct effects & 2.7 & $\$ 183.1$ & $\$ 316.0$ \\
Secondary effects & 7.1 & $\$ 516.6$ & $\$ 878.1$ \\
Total economic impact & & & \\
\hline
\end{tabular}

\section{Summary of Economic Impacts for Alternative A (No Action Alternative)}

Table 9 summarizes the direct and total economic impacts in the three-county area of Refugemanagement activities for Alternative A. Under Alternative A, Don Edwards San Francisco Bay NWR management activities directly related to Refuge operations would generate an estimated 17 jobs, $\$ 850,100$ in labor income, and $\$ 1.42$ million in value added in the local economy. Including direct, indirect, and induced effects, all Don Edwards San Francisco Bay NWR activities would generate a total economic impact of 30 jobs, \$1.62 million in labor income, and \$2.77 million in value added. In 2009,

Table 9. Economic impacts of Don Edwards San Francisco Bay National Wildlife Refuge management activities for Alternative A.

\begin{tabular}{|c|c|c|c|}
\hline & $\begin{array}{c}\text { Employment } \\
\text { (number of full- } \\
\text { and part-time jobs) }\end{array}$ & $\begin{array}{c}\text { Labor income } \\
\text { (in thousands of dollars, } \\
\text { 2010) }\end{array}$ & $\begin{array}{c}\text { Value added } \\
\text { (in thousands of dollars, } \\
\text { 2010) }\end{array}$ \\
\hline \multicolumn{4}{|c|}{ Refuge administration $^{a}$} \\
\hline Direct effects & 3.1 & $\$ 234.6$ & $\$ 395.4$ \\
\hline Total effects & 9.2 & $\$ 594.7$ & $\$ 1,035.4$ \\
\hline \multicolumn{4}{|c|}{ Public use activities } \\
\hline Direct effects & 13.4 & $\$ 615.5$ & $\$ 1,027.7$ \\
\hline Total effects & 21.0 & $\$ 1,022.1$ & $\$ 1,729.7$ \\
\hline \multicolumn{4}{|c|}{ Aggregate impacts } \\
\hline Direct effects & 16.5 & $\$ 850.1$ & $\$ 1,423.1$ \\
\hline Total effects & 30.2 & $\$ 1,616.8$ & $\$ 2,765.1$ \\
\hline
\end{tabular}

${ }^{\mathrm{a}}$ Staff salary purchases and work related purchases 
total labor income was estimated at $\$ 190$ billion and total employment was estimated at 2.42 million jobs for the local three-county area (Minnesota IMPLAN Group, Inc., 2010). Thus, total economic impacts associated with Don Edwards San Francisco Bay NWR operations under Alternative A represent less than one hundredth of one percent of total income ( 0.0008 percent) and total employment $(0.001$ percent $)$ in the overall three-county area economy. Total economic effects of Refuge operations play a much larger role in the communities near the Refuge where most of the Refuge-related expenditures and public-use-related economic activity occur.

\section{Summary of Economic Impacts for Alternative B}

Table 10 summarizes the direct and total economic impacts in the three-county area of Refugemanagement activities for Alternative B. Under Alternative B, Don Edwards San Francisco Bay NWR management activities directly related to Refuge operations would generate an estimated 22 jobs, $\$ 1.14$ million in labor income, and \$1.91 million in value added in the local economy. Including direct, indirect, and induced effects, all Don Edwards San Francisco Bay NWR activities would generate a total economic impact of 43 jobs, \$2.34 million in labor income, and \$4.02 million in value added. Total economic impacts associated with Don Edwards San Francisco Bay NWR operations under Alternative $B$ represent less than one hundredth of one percent of total income ( 0.001 percent) and total employment ( 0.002 percent) in the overall three-county area economy. Total economic effects of Refuge operations play a much larger role in the communities near the Refuge where most of the Refuge-related expenditures and public-use-related economic activity occur.

Table 10. Economic impacts of Don Edwards San Francisco Bay National Wildlife Refuge management activities for Alternative B.

\begin{tabular}{|c|c|c|c|}
\hline & $\begin{array}{c}\text { Employment } \\
\text { (number of full- and } \\
\text { part-time jobs) }\end{array}$ & $\begin{array}{c}\text { Labor income } \\
\text { (in thousands of dollars, } \\
2010 \text { ) }\end{array}$ & $\begin{array}{c}\text { Value added } \\
\text { (in thousands of dollars, } \\
\text { 2010) }\end{array}$ \\
\hline \multicolumn{4}{|c|}{ Refuge administration $^{\text {a }}$} \\
\hline Direct effects & 4.6 & $\$ 344.1$ & $\$ 579.9$ \\
\hline Total effects & 16.2 & $\$ 1020.4$ & $\$ 1786.1$ \\
\hline \multicolumn{4}{|c|}{ Public use activities } \\
\hline Direct effects & 17.3 & $\$ 795.3$ & $\$ 1,328.0$ \\
\hline Total effects & 27.2 & $\$ 1,320.9$ & $\$ 2,235.4$ \\
\hline \multicolumn{4}{|c|}{ Aggregate impacts } \\
\hline Direct effects & 21.9 & $\$ 1,139.4$ & $\$ 1,907.9$ \\
\hline Total effects & 43.4 & $\$ 2,341.4$ & $\$ 4,021.6$ \\
\hline
\end{tabular}

${ }^{\mathrm{a}}$ Staff salary purchases and work related purchases

Table 11 summarizes the change in economic effects associated with Don Edwards San Francisco Bay NWR operations under Alternative B as compared to Alternative A. Due to increases in Refuge visitation and administration, Alternative B would generate 13 more jobs, $\$ 724,500$ more in labor income, and \$1.26 million more in value added as compared to Alternative A. 
Table 11. Change in economic impacts under Alternative B compared to Alternative A.

\begin{tabular}{|c|c|c|c|}
\hline & $\begin{array}{l}\text { Employment } \\
\text { (number of full- and } \\
\text { part-time jobs) }\end{array}$ & $\begin{array}{c}\text { Labor income } \\
\text { (in thousands of dollars, } \\
\text { 2010) }\end{array}$ & $\begin{array}{c}\text { Value added } \\
\text { (in thousands of dollars, } \\
\text { 2010) }\end{array}$ \\
\hline \multicolumn{4}{|c|}{ Refuge administration $^{a}$} \\
\hline Direct effects & 1.5 & $\$ 109.5$ & $\$ 184.5$ \\
\hline Total effects & 7.0 & $\$ 425.7$ & $\$ 750.8$ \\
\hline \multicolumn{4}{|c|}{ Public use activities } \\
\hline Direct effects & 3.9 & $\$ 179.8$ & $\$ 300.3$ \\
\hline Total effects & 6.2 & $\$ 298.8$ & $\$ 505.7$ \\
\hline \multicolumn{4}{|c|}{ Aggregate impacts } \\
\hline Direct effects & 5.4 & $\$ 289.3$ & $\$ 484.8$ \\
\hline Total effects & 13.2 & $\$ 724.5$ & $\$ 1,256.5$ \\
\hline
\end{tabular}

${ }^{\mathrm{a}}$ Staff salary purchases and work related purchases

\section{Summary of Economic Impacts for Alternative C}

Table 12 summarizes the direct and total economic impacts in the three-county area of Refugemanagement activities for Alternative C. Under Alternative C, Don Edwards San Francisco Bay NWR management activities directly related to Refuge operations would generate an estimated 23 jobs, \$1.19 million in labor income, and $\$ 1.99$ million in value added in the local economy. Including direct, indirect, and induced effects, all Don Edwards San Francisco Bay NWR activities would generate a total economic impact of 47 jobs, \$2.5 million in labor income, and \$4.29 million in value added. Total economic impacts associated with Don Edwards San Francisco Bay NWR operations under Alternative $\mathrm{C}$ represent less than one hundredth of one percent of total income ( 0.001 percent $)$ and total employment ( 0.002 percent $)$ in the overall three-county area economy. Total economic effects of Refuge operations play a much larger role in the communities near the Refuge where most of the Refuge-related expenditures and public-use-related economic activity occur.

Table 12. Economic impacts of Don Edwards San Francisco Bay National Wildlife Refuge management activities for Alternative C.

\begin{tabular}{|c|c|c|c|}
\hline & $\begin{array}{l}\text { Employment } \\
\text { (number of full- and } \\
\text { part-time jobs) }\end{array}$ & $\begin{array}{c}\text { Labor income } \\
\text { (in thousands of dollars, } \\
2010 \text { ) }\end{array}$ & $\begin{array}{c}\text { Value added } \\
\text { (in thousands of dollars } \\
2010 \text { ) }\end{array}$ \\
\hline \multicolumn{4}{|c|}{ Refuge administration $^{\mathrm{a}}$} \\
\hline Direct effects & 4.4 & $\$ 333.5$ & $\$ 562.1$ \\
\hline Total effects & 17.3 & $\$ 1075.5$ & $\$ 1,887.3$ \\
\hline \multicolumn{4}{|l|}{ Public use activities } \\
\hline Direct effects & 18.7 & $\$ 855.9$ & $\$ 1,429.1$ \\
\hline Total effects & 29.3 & $\$ 1,421.5$ & $\$ 2,405.6$ \\
\hline \multicolumn{4}{|l|}{ Aggregate impacts } \\
\hline Direct effects & 23.1 & $\$ 1,189.4$ & $\$ 1,991.2$ \\
\hline Total effects & 46.5 & $\$ 2,497.0$ & $\$ 4,292.9$ \\
\hline
\end{tabular}

${ }^{\mathrm{a}}$ Staff salary purchases and work related purchases 
Table 13 summarizes the change in economic effects associated with Don Edwards San Francisco Bay NWR operations under Alternative $\mathrm{C}$ as compared to Alternative A. Due to increases in Refuge visitation and administration, Alternative $C$ would generate 16 more jobs, $\$ 880,200$ more in labor income, and $\$ 1.53$ million more in value added as compared to Alternative A.

Table 13. Change in economic impacts under Alternative $C$ compared to Alternative $A$.

\begin{tabular}{|c|c|c|c|}
\hline & $\begin{array}{c}\text { Employment } \\
\text { (number of full- and } \\
\text { part time jobs) }\end{array}$ & $\begin{array}{c}\text { Labor income } \\
\text { (in thousands of dollars, } \\
\text { 2010) }\end{array}$ & $\begin{array}{c}\text { Value added } \\
\text { (in thousands of dollars, } \\
\text { 2010) }\end{array}$ \\
\hline \multicolumn{4}{|c|}{ Refuge administration $^{\mathrm{a}}$} \\
\hline Direct effects & 1.3 & $\$ 98.9$ & $\$ 166.7$ \\
\hline Total effects & 8.1 & $\$ 480.8$ & $\$ 851.9$ \\
\hline \multicolumn{4}{|c|}{ Public use activities } \\
\hline Direct effects & 5.3 & $\$ 240.3$ & $\$ 401.4$ \\
\hline Total effects & 8.2 & $\$ 399.4$ & $\$ 675.9$ \\
\hline \multicolumn{4}{|c|}{ Aggregate impacts } \\
\hline Direct effects & 6.6 & $\$ 339.2$ & $\$ 568.1$ \\
\hline Total effects & 16.3 & $\$ 880.2$ & $\$ 1,527.9$ \\
\hline
\end{tabular}

${ }^{\mathrm{a}}$ Staff salary purchases and work related purchases

\section{Summary and Conclusions}

Under Alternative A, the Don Edwards San Francisco Bay National Wildlife Refuge management activities directly related to Refuge operations generate an estimated 30 jobs, $\$ 1.62$ million in labor income, and $\$ 2.77$ million in value added in the local economy. Due to increases in Refuge administration and public-use activities, Alternative B would generate 13 more jobs, $\$ 724,500$ more in labor income, and \$1.26 million more in value added as compared to Alternative A. Under Alternative $\mathrm{C}$, refuge public-use and administration activities would increase. Alternative $\mathrm{C}$ would generate 16 more jobs, $\$ 880,200$ more in labor income, and $\$ 1.53$ million more in value added as compared to Alternative A. Total economic impacts associated with Don Edwards San Francisco Bay NWR operations across all Alternatives represent less than one hundredth of one percent of total income and total employment in the overall three-county local economy. The total economic effects of Refuge operations play a much larger role in the communities near the Don Edwards San Francisco Bay NWR where most of the Refuge-related expenditures and public-use-related economic activity occurs.

\section{Appendix}

As mentioned previously, when determining the economic impacts of visitor spending, only spending by non-locals is included in the analysis. This spending generates new income and employment, and has an economic impact on the region. Evaluating this spending shows the economic gain that the Refuge provides to the region (Carver and Caudill, 2007). In this Appendix, total spending by both locals and non-locals is evaluated to show the significance of the Don Edwards San Francisco Bay NWR to the local economy under the current Alternative A. As noted by Carver and Caudill (2007), significance shows the economic activity in a region that is connected to refuge activities, but does not reflect income and employment that would be lost if the refuge were not a part of that economy. 
Table 1-1 shows local and non-local visitation to the Don Edwards San Francisco Bay NWR under the current Alternative A. To capture spending by local visitors, we used the spending profiles in Carver and Caudill (2007) for residents for FWS Region 1 and updated the 2006 spending profiles to 2010 dollars using the Consumer Price Index Inflation Calculator. Average-daily-spending profiles for resident visitors to Region 1 for fishing ( $\$ 39.57$ per-day) and waterfowl and other migratory bird hunting (\$53.88 per-day) were used to estimate local visitor spending for Refuge fishing and hunting related activities. The average daily resident spending profile for non-consumptive wildlife recreation (observing, feeding, or photographing fish and wildlife) was used for non-consumptive wildlife viewing activities (\$32.33 per-day). Total spending by local Refuge visitors was determined by multiplying the average local visitor daily spending by the number of local visitor days at the Refuge. Table 2-1 summarizes the total economic significance associated with both local and non-local visitation under the current Alternative A.

Table 1-1. Estimated annual Don Edwards San Francisco Bay National Wildlife Refuge local and non-local visitation by visitor activity for Alternative $A$.

\begin{tabular}{lrrrrrr}
\hline & $\begin{array}{c}\text { Total } \\
\text { number } \\
\text { of visits }\end{array}$ & $\begin{array}{c}\text { Number of } \\
\text { local } \\
\text { visits }\end{array}$ & $\begin{array}{c}\text { Number } \\
\text { of non- } \\
\text { local } \\
\text { visits }\end{array}$ & $\begin{array}{c}\text { Number of } \\
\text { hours spent } \\
\text { at refuge }\end{array}$ & $\begin{array}{c}\text { Number } \\
\text { local } \\
\text { visitor } \\
\text { days }\end{array}$ & $\begin{array}{c}\text { Number of } \\
\text { non-local } \\
\text { visitor } \\
\text { days }^{\mathbf{a}}\end{array}$ \\
\hline $\begin{array}{l}\text { Alternative } \mathbf{A} \\
\quad \text { Fishing }\end{array}$ & 3,700 & 3,330 & 370 & 4 & 1,665 & 185 \\
$\quad \begin{array}{l}\text { Waterfowl hunting } \\
\quad \begin{array}{l}\text { Nature trails/other wildlife } \\
\text { observation }\end{array}\end{array}$ & 3,900 & 3,510 & 390 & 6 & 2,633 & 293 \\
$\quad$\begin{tabular}{l} 
Total visitation \\
\hline
\end{tabular} & 746,341 & 671,707 & 74,634 & 2 & 167,927 & 18,659 \\
\hline
\end{tabular}

${ }^{\mathrm{a}}$ One visitor day $=8$ hours

Table 1-2. Total annual impacts of local and non-local visitor spending for Alternative A.

\section{Employment (number of full- and part-time jobs)}

Labor income (in thousands of dollars, 2010)
Value added (in thousands of dollars, 2010)

\begin{tabular}{lrrr}
\hline Local spending & & & \\
$\quad$ Direct effects & 34.7 & $\$ 1,528.1$ & $\$ 2,535.9$ \\
$\quad$ Secondary effects & 17.2 & $\$ 1,001.3$ & $\$ 1,732.3$ \\
$\begin{array}{l}\text { Total economic } \\
\text { significance }\end{array}$ & 51.9 & $\$ 2,529.4$ & $\$ 4,268.2$ \\
\hline Non-local spending & & & \\
$\quad$ Direct effects & 13.4 & $\$ 615.5$ & $\$ 1,027.7$ \\
$\quad$ Secondary effects & 7.6 & $\$ 106.6$ & $\$ 702.0$ \\
Total economic impact & 21.0 & $\$ 3,022.1$ & $\$ 5.729 .7$ \\
Total economic & 72.9 & & $\$ 5,997.9$ \\
significance & & & \\
\hline
\end{tabular}




\section{References}

Bureau of Labor Statistics-United States Department of Labor, 2011, Labor force statistics from the current population survey, accessed June 3, 2011, at http://www.bls.gov/data/\#unemployment.

California Department of Fish and Game, 2011, Existing marine protected areas in CaliforniaRegulations, accessed June 4, 2011, at http://www.dfg.ca.gov/mlpa/mpa_regs.asp\#commercial.

California Department of Fish and Game, 2010, PUB-Poundage and value of landings by port: San Francisco area during 2009, Table 17.

California State Parks, 2009, California outdoor recreation plan 2008.

Cargill, Inc., 2005, A history of cooperation, accessed June 4, 2011, at http://www.cargill.com/cs/sf_bay/saltpond_cooperation.htm.

Carver, E., and Caudill, J., 2007, Banking on nature 2006-The economic benefits to local communities of national wildlife refuge visitation: Washington D.C., Division of Economics, U.S. Fish and Wildlife Service.

Department of Parks-San Mateo County, 2011, What to do in San Mateo county parks?, accessed June 3, 2011, at http://www.co.sanmateo.ca.us/portal/site/parks/menuitem16bfc0a32453ee4482439054d17332a0/?vgn extoid=4a0d59d73620e210VgnVCM1000001937230aRCRD\&vgnextchannel=2a0d59d73620e210Vg nVCM1000001937230a_\&vgnextfmt=DivisionsLanding

Department of Parks and Recreation-Santa Clara County, 2011, Find a park, accessed June 4, 2011, at http://www.sccgov.org/portal/site/parks/parkschp?path $=\% 2 F v 7 \% 2$

FParks\%20and\%20Recreation\%2C\%20Department\%20of\%20\%28DEP\%29\%2Fmain_menu\%2FHi story\%20Here.

Department of Planning, Building, and Code Enforcement-City of San Jose, 2011, Fact sheet-History and geography.

Employment Development Department, 2011a, Labor market info-Overview: California, accessed June 7, 2011, at http://www.labormarketinfo.edd.ca.gov/?pageied $=131$.

Employment Development Department, 2011b, Cities and census designated places by individual county: California, accessed June 5, 2011, at http://www.labormarketinfo.edd.ca.gov/?pageid=133.

Markoff, John, 2009, Searching for Silicon Valley: New York Times-Escapes, published April 16, 2009, accessed June 7, 2011, at http://travel.nytimes.com/2009/04/17/travel/escapes/17Amer.html?pagewanted $=1$

Minnesota IMPLAN Group, Inc., 2010, Year 2009 IMPLAN data files, www.implan.com.

Office of Economic Development-City of San Jose, 2010, Data on major high tech employers.

Olson, D., and Lindall, S., 1999, IMPLAN professional software, analysis and data guide: Minnesota, IMPLAN Group, Inc.

Parks, Recreation and Neighborhood Services- City of San Jose, 2009, Annual report 2009.

Recreation and Community Service-Newark, 2011, Our beautiful Newark parks!, accessed June 6, 2011, at http://www.newark.org/residents/ parks/

Recreation Services, City of Fremont, 2011, Fremont recreation facts, accessed June 10, 2011, at http://www.fremont.gov/index.aspx? nid=259.

San Francisco Bay Wildlife Society, 2010, About us, accessed June 5, 2011, at http://sfbws.org/about.htm.

Smith, S.E., and Kato, S., 1979, The fisheries of San Francisco Bay-Past, present, and future: Pacific Division of the American Association for the Advancement of Science.

Stynes, D., 1998 Guidelines for measuring visitor spending: Department of Parks, Recreation and Tourism Resources, Michigan State University. 
U.S. Census Bureau, 2010, State and county QuickFacts, accessed June 4, 2011, at http://quickfacts.census.gov/qfd/index.html.

U.S. Census Bureau, 2011, 2010 Census demographic profiles, accessed June 4, 2011, at http://2010.census.gov/2010census/data/

U.S. Census Bureau, 2009a, 2006-2008 American community survey 3-year estimates: American FactFinder.

U.S. Census Bureau, 2009b, Small area income and poverty estimates, accessed June 7, 2011, at http://www.census.govl/did/www/saipe/.

U.S. Fish and Wildlife Service, 2003, Don Edwards San Francisco Bay National Wildlife Refuge. Refuge Brochure, March, accessed June 3, 2011, at http://library.fws.gov/refuges/DEsanfran.pdf.

U.S. Fish and Wildlife Service and U.S. Census Bureau, 2008, 2006 National survey of fishing, hunting, and wildlife associated recreation.

Publishing support provided by:

Denver Publishing Service Center

For more information concerning this publication, contact:

Center Director, USGS Fort Collins Science Center

2150 Centre Ave., Bldg. C

Fort Collins, CO 80526-8118

(970) 226-9398

Or visit the Fort Collins Science Center Web site at:

http://www.fort.usgs.gov/ 